\title{
WHAT CAN WE LEARN FROM BOBTAIL SQUID?
}

SARAH MCANULTY FROM THE UNIVERSITY OF CONNECTICUT IS LOOKING AT A VERY INTRIGUING RELATIONSHIP BETWEEN A BACTERIA AND BOBTAIL SQUID. WHY? HER WORK COULD TELL US A LOT ABOUT HOW OUR OWN IMMUNE SYSTEMS COMMUNICATE WITH - AND NEED - 'GOOD' BACTERIA.

\section{SOME BACTERIA \\ IS GOOD FOR US}

There are 'good' and 'bad' bacteria. Of course, bad bacteria are those that make humans sick. But some bacteria are beneficial to humans; and without them, we wouldn't survive. They help us to digest our food and fight disease, for example.

Interestingly, many other animals cultivate beneficial relationships with bacteria, too. Imagine what we could learn from these relationships, and from studying the immune systems that regulate them. Could this knowledge help humans to boost their immune systems and better fight disease? What do you think?

\section{SARAH'S TOP TIPS FOR}

\section{GETTING INTO MARINE SCIENGE}

1. Volunteer to help with animal care

1. and conservation

At college, get involved with

2. research as soon as you can you throughout your studies and working life
The term 'symbiosis' describes the interaction between two different organisms living in close association. Oftentimes, these interactions are advantageous to both organisms and help them to survive.

They may, for example, share their habitats or food. Or sometimes, the by-product of one organism's behaviour is beneficial to another.

Sarah McAnulty from the University of Connecticut has been studying an intriguing symbiotic relationship between a type of bacteria and the Hawaiian bobtail squid. She hopes to better understand their unique interaction and how the squid's immune system mediates it.

WHAT DO WE KNOW ABOUT THE HAWAIIAN BOBTAIL SQUID?

The Hawaiian bobtail squid (Euprymna scolopes) is found in the shallow waters of coastal Hawaii. The squid has amazing camouflaging abilities in that it's able to 'disappear' as it swims through open waters at night. The squid's secret lies in a symbiotic relationship with a certain species of bacteria (Vibrio fischeri) that lives in its light organ.

HOW DOES THE CAMOUFLAGING SYSTEM WORK?

"The squid's light organ is a two-sided pouch that holds bioluminescent bacteria - V. fischeri," Sarah explains. "There is a filter that ensures the right colour light is emitted. There are even little areas of silver tissue that act like reflectors to control the light. All of that is surrounded by an ink sac."

How does this translate into open-water camouflaging abilities? Well, when the squid enters open waters to hunt at night, the bacteria emits a certain kind of light; in return for a sugary, amino acid solution. The light that $V$. fischeri emits is almost identical to the moonlight that is shining down on the squid from above. The result? The squid is virtually invisible to predators looking up from the seafloor. Sarah explains that this camouflage technique is known as 'counterillumination'. I'm sure you would agree with Sarah when she says, "The symbiosis between $V$. fischeri and Hawaiian bobtail squid is super cool!"

\section{HOW DOES THE SQUID SEEK OUT} AND COLLECT V. FISCHERI?

Sarah admits that this is quite a challenging question to answer. There are incredible hurdles that the bacteria must overcome to find its way into the light organ. For example, they need to survive nasty chemicals outside the light organ, actively swim down special ducts, and then survive other internal chemicals on their journey to the light organ.

At this stage, it appears that the bacteria's success has something to do with the squid's 



\section{政 ASK SARAH MCANULTY}

DID YOU ALWAYS WANT TO BE A SCIENTIST FROM AN EARLY AGE?

When I was really young, I wanted to be a palaeontologist, but when I was about 8, I switched over to marine biology.

WHO OR WHAT INSPIRED YOU TO FOLLOW A CAREER IN MARINE BIOLOGY?

When I was a kid, my mom took me to the library ALL the time. There was this one video that was my absolute favourite. It was a National Geographic Kids video all about the ocean called 'Really Wild Animals'. There was a scene about halfway through that introduced the cuttlefish. I was immediately obsessed with cuttlefish and it's been that way ever since!

YOU'RE CURRENTLY A PHD

CANDIDATE. WHAT DOES THIS MEAN?

That means that I'm in school studying to get a $\mathrm{PhD}$. At this point, school really looks more like a full-time job than the school you might be familiar with now. I work in the lab, do experiments, process data, and then write it up and share it with people. I used to take classes, but I'm far enough along now that I don't have to take any more.

\section{WHAT DO YOU HAVE TO DO TO} BECOME DR SARAH MCANULTY?

I just need to write up my data, publish it, and then write my thesis. I've already started the finishing process, so l'll be $\operatorname{Dr} M c$ Anulty some time next summer.

WHAT DO YOU LOVE MOST ABOUT YOUR WORK?

I love feeding baby squid and sharing my squid and science with other people. Talking about science is one of my favourite things to do and getting other people excited about squid and marine biology gets me out of bed in the morning.
YOU HAVE CREATED A SPECIAL SCIENCE COMMUNICATION INITIATIVE CALLED 'SKYPE A SCIENTIST'. WHAT IS SKYPE A SCIENTIST?

Skype a Scientist is an initiative in which we match scientists with classrooms or groups of adults for 30- to 60-minute Q\&A sessions about the scientist's area of expertise. It's really that simple. Teachers or other group leaders can request a scientist by filling out a Google form. Then they'll get their match within two weeks. Teachers can request a scientist from 24 different categories to match up with what the students are learning in class, and even request a scientist of a specific under-represented group so that students in the class see a scientist that looks like them.

HOW DID YOU COME UP WITH THE IDEA?

The idea came from an observation I made. I noticed a growing distrust towards science, both in the media and on the internet - it really seemed like a mess! In trying to understand why people weren't trusting science, I searched 'scientists' and the results were bleak - it wasn't very representative of the diversity in STEM that l've seen in my career. I figured if I could find a way to get real scientists talking to people that it may help the situation. I wanted to help people to know and trust real scientists. And the best way to do that is to just meet them! That's what Skype a Scientist is all about.

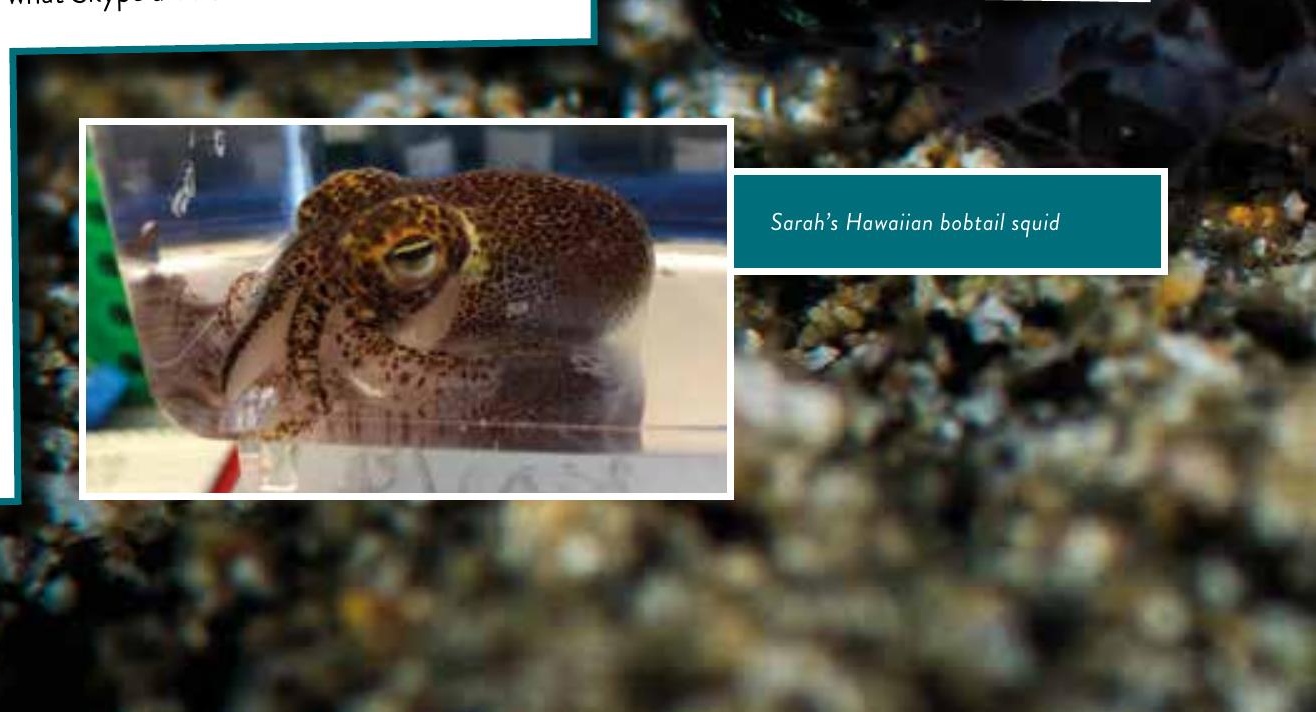




\section{. SKYPE A SCIENTIST}

OVER 2,000 SCIENTISTS HAVE SIGNED UP TO SKYPE A SCIENTIST TO CHAT ABOUT THEIR WORK TO SCHOOL AND COLLEGE KIDS ALL AROUND THE WORLD. WHETHER YOU'RE A STUDENT OR TEACHER, FIND OUT HOW YOU CAN BOOK IN A SKYPE SESSION WITH ANY ONE OF THESE AMAZING PEOPLE.

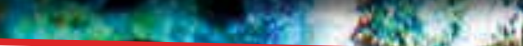

When you think about the word 'scientist', what comes to mind? Perhaps a certain type of person, wearing a certain type of clothing, doing something 'sciency'. But are your preconceptions about scientists correct? The truth is, scientists come from a whole range of different backgrounds, and they work in a whole range of interesting jobs. Related to this is a perceived disconnect between scientists and members of the public. Again, it's based on misconceptions - that scientists fit a certain profile and, in many cases, are unapproachable.

Sarah wanted to do something about this. She wanted to break down barriers between scientists and school students and open up dialogue between them. To achieve this goal, she created the so-called 'Skype and Scientist' initiative.

\section{WHAT IS SKYPE A SCIENTIST?}

Skype a Scientist is about connecting the lab to the classroom and encouraging students to get to know real scientists. Just imagine, you're sitting in class and on the projector screen - live in front of you - is a friendly, enthusiastic and knowledgeable scientist ready to answer your questions.

WHAT DO STUDENTS GET OUT OF SKYPE A SCIENTIST?

In addition to answering their questions, Skype a Scientist allows students to get a glimpse into life as a scientist. This is a notable feature because, as Sarah points out, "many of the examples of scientists in TV and movies are not particularly realistic, so seeing real scientist life can help folks decide whether science might be for them." So, students get some much-needed guidance. Perhaps it's the encouragement they need to reach out for a career in STEM.

Another benefit is that students, whether they're into science or not, learn to differentiate real science and real scientists from the often-inaccurate representations in the media. This is an invaluable skill and helps us to make informed decisions about society. “Even if young people know they don't want to become a scientist, I think seeing what science is all about is really important for everyone, because it can dispel a lot of the myths about the science you may see on TV," says Sarah.

HOW DO YOU CONNECT WITH A SCIENTIST?

Teachers or other group leaders can request a scientist by filling out a Google form and then they'll get their match within two weeks. But Sarah also explained that students can contact Skype a Scientist directly. The only condition is that you a need a minimum of seven people to have a session.

WHO MIGHT YOU CONNECT WITH THROUGH SKYPE A SCIENTIST?

You'll be able to connect with all sorts of different people through Skype a Scientist. Below is one scientist out of over 2,000 who are willing and able to talk to you about their research:

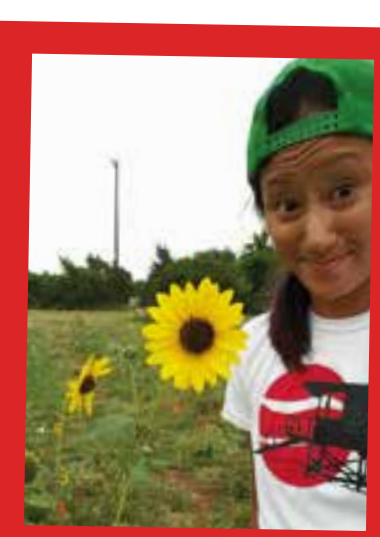

NAME: Nora Mitchell

TITLE: Postdoctoral Fellow at The University of New Mexico

WHAT DO YOU DO?: I study hybridisation and evolution

in Texas sunflowers! I want to show students around the world that there's no one way to be a scientist, and that \#plantsarecooltoo!

NUMBER OF SKYPE SESSIONS: 7 